Scientific Visualization, 2019, volume 11, number 5, pages 126 - 141, DOI: 10.26583/sv.11.5.11

\title{
Computer visualization of the identify industrial clusters task using GVMap
}

\author{
E.V. Kozonogova1, D.S. Kurushin2, J.V. Dubrovskaya3 \\ Perm National Research Polytechnic University \\ 1 ORCID: 0ooo-0oo1-9573-7336, elenaa.semenovaa@gmail.com \\ 2 ORCID: 0000-0003-4798-7423, dan973@yandex.ru \\ 3 ORCID: 0000-0002-3205-9264, uliadubrov@mail.ru
}

\begin{abstract}
On the basis of systematization ways of reflection the interactions of cluster relations subjects the technique of visualization of identification industrial clusters is presented. As a visualization tool used GVmap, implemented in the software "Graphviz". Identification of clusters at the macro level is based on the symmetric table "input-output" in the context of 86 economic activities. The input parameters were data in the form of a graph and information about clustering in the data. Economic activities are selected as the vertices of the graph. The connections between the vertices of the graph (edge) were constructed on the basis of the matrix of significant supplier-consumer relations obtained by the Maximum method. Clusters of industries are calculated using the method of Zamanski.

Tool GVMap clustered the data displayed geographic-like maps to the image that not only makes it easier to read the graph connectivity of economic sectors, much as you would to shape an adequate development strategy for enterprises to cluster and for the areas of their localization.

To automate the process of industrial clusters identification and their visualization, a software tool in Python was created. 00562.

The reported study was funded by RFBR according to the research project № 19-010-
\end{abstract}

Keywords: GVMap, data visualization, identification of clusters, the method of S. Zamansky, the method of maximum, geographic-like maps.

\section{Introduction}

Clustering is one of the main development directions of state industrial policy in Russia. At the beginning of 2018, there were 115 clusters in Russia on the territory of 43 entities. They include about 3,500 enterprises with more than 1,400 thousand employees [1]. For the period 2013-2018 the total amount of subsidies exceeded 12 billion rubles [2].

The active support of the clusters by the authorities has influenced the emergence of a significant amount of research and publications in this area. Scientists use various visualization methods to simplify the understanding of the studied relationships between cluster components. At the same time, visualization in this particular case is necessary not so much for convenient perception of the information being studied as for simplifying its analysis, further processing and making forecasts.

In this regard, we note that the cluster policy of the state is directly related to the development of individual industries in specific regions of the country. The limitations of both budgetary and extra-budgetary financing necessitates an adequate quantitative justification for the selection of priority sectors and regions, investments in which are able to provide maximum utility. At the same time, given the scale of the national economy and the high di- 
versification of its sectoral structure, the ability to obtain a holistic visual representation of the relevant statistical data is of particular importance when implementing cluster policy. Moreover, it is not just about providing options for the perception, assessment and analysis of available information. First of all, the goal of visual presentation of data on economic clustering is to provide the ability to model and predict the behavior of the clustered industry.

Thus, on the basis of the foregoing, it can be summarized that the visualization of the task of identifying industrial clusters is the core feature for constructing plans, forecasts and development strategies for both individual industries and regions, and the national economy as a whole.

\section{Systematization of existing methods for visualizing relationships between cluster entities}

The use of visual methods for displaying the results of modeling the interactions of cluster relations subjects is designed to simplify the implementation of planning, forecasting, programming, and strategy tasks. A review of the scientific literature on the problems of clustering the economy revealed that existing works in this field from the point of visualization can be divided into three groups. Let's consider them in more detail.

To the first group we refer works in which researchers attempted to systematize the essential properties and attributes of clusters. These works contain models formulated at the verbal level and based on certain theoretical concepts. As a rule, the models of the first group reflect the relations between the subjects of the clusters $[3$, p. 25; 4, p. 6; 5, p. 31; 6, p. 13]; stages of their formation (life cycles of clusters) $[7$, p. 9; 8, p. 17; 9, p. 27]; cluster creation conditions $[10$, p. $3 ; 11$, p. eighteen]; features of the formation of cluster initiatives [12, p. 58; 7, p. 9]; structures and types of clusters [8, p. 85; 11, p. 191]. Examples of models visualizing the theoretical concepts of cluster development are presented in Figure 1.

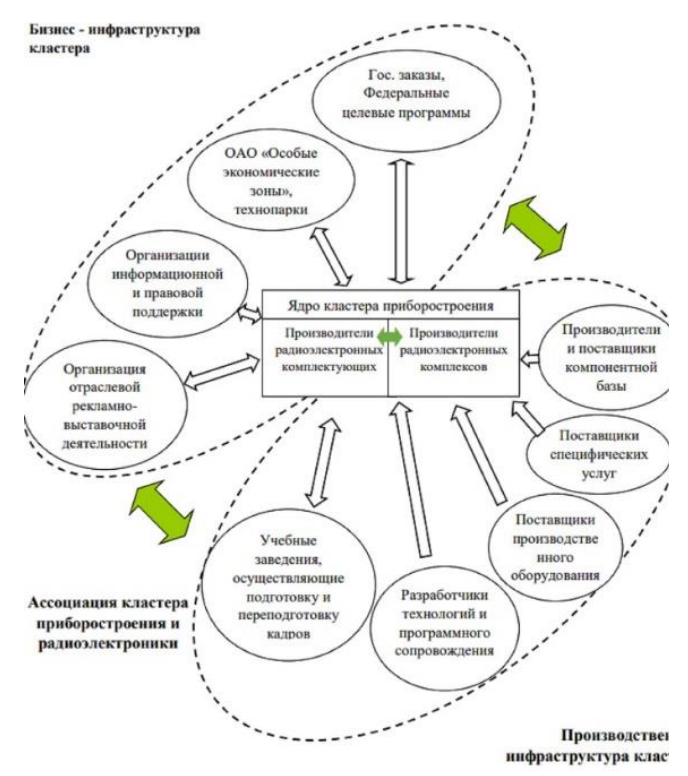

a) instrument engineering cluster structure [13, p. 29]

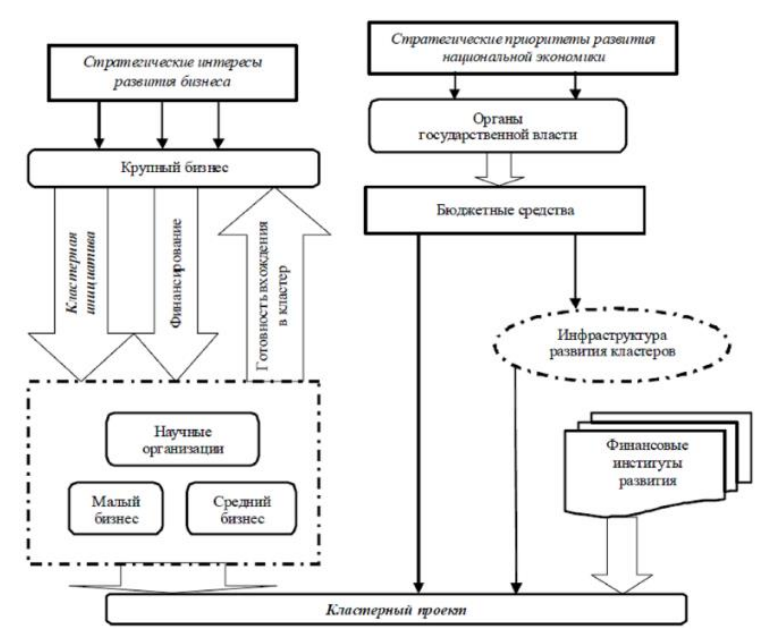

b) a model for the formation of cluster initiatives [12, p. 58] 


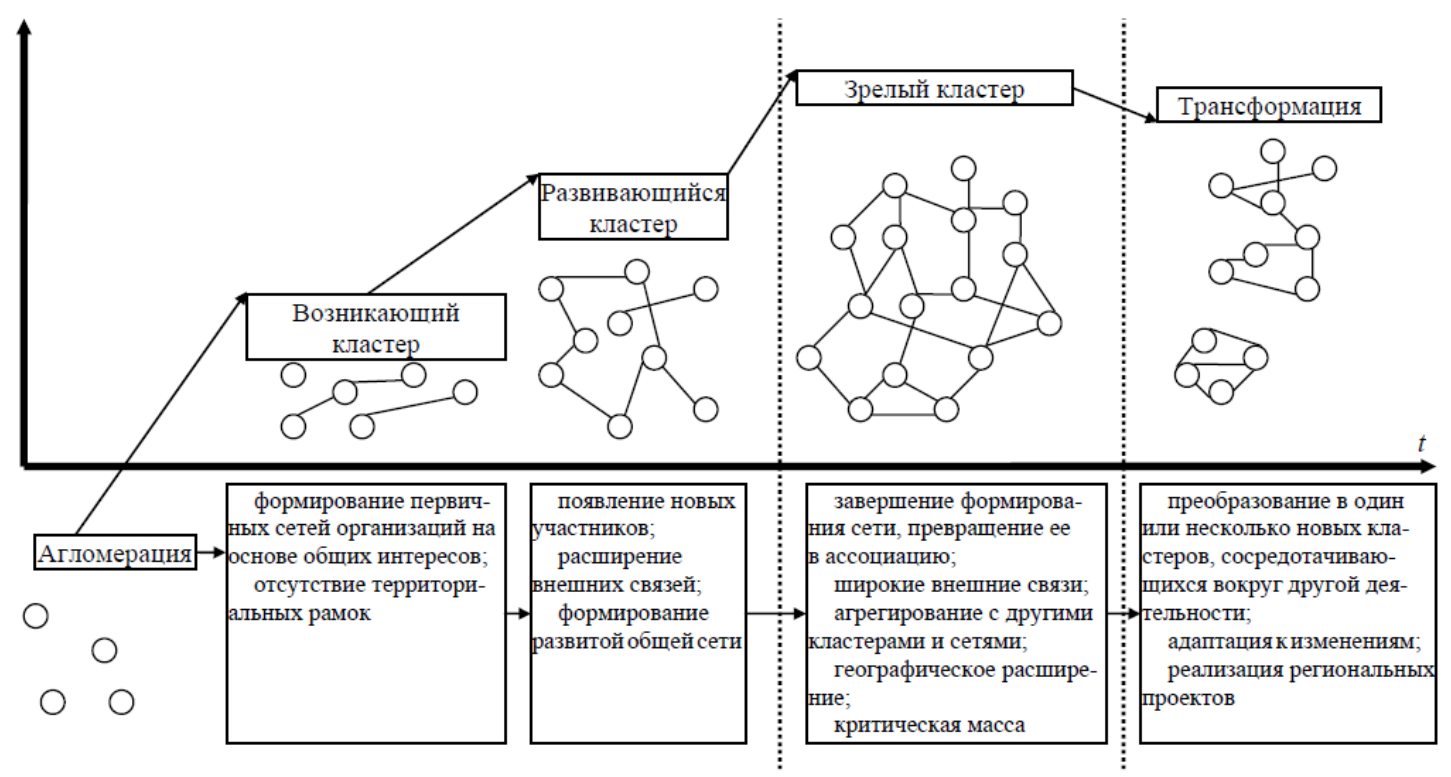

c) cluster life cycle $[8$, p. 27]

Fig. 1. Examples of theoretical concepts visualization for cluster development

The main advantage of the models in this group is the availability of understanding for the theoretical foundations of clustering; as a drawback, we note the low adaptability of the model information use to build forecasts and development strategies for both specific clusters and their localization territories.

In the second group we included works containing a visual representation of actual statistical information regarding various characteristics of clusters at a specific date and for specific territories: the number of clusters and their types [14, p. 22; 15, p. 52; 16, p. 188]; cluster development parameters [15, p. 49-51; 17, p. one hundred]; sources of cluster financing [18, p. 46] and others. Examples of models visualizing the quantitative characteristics of clusters are presented in Figure 2.

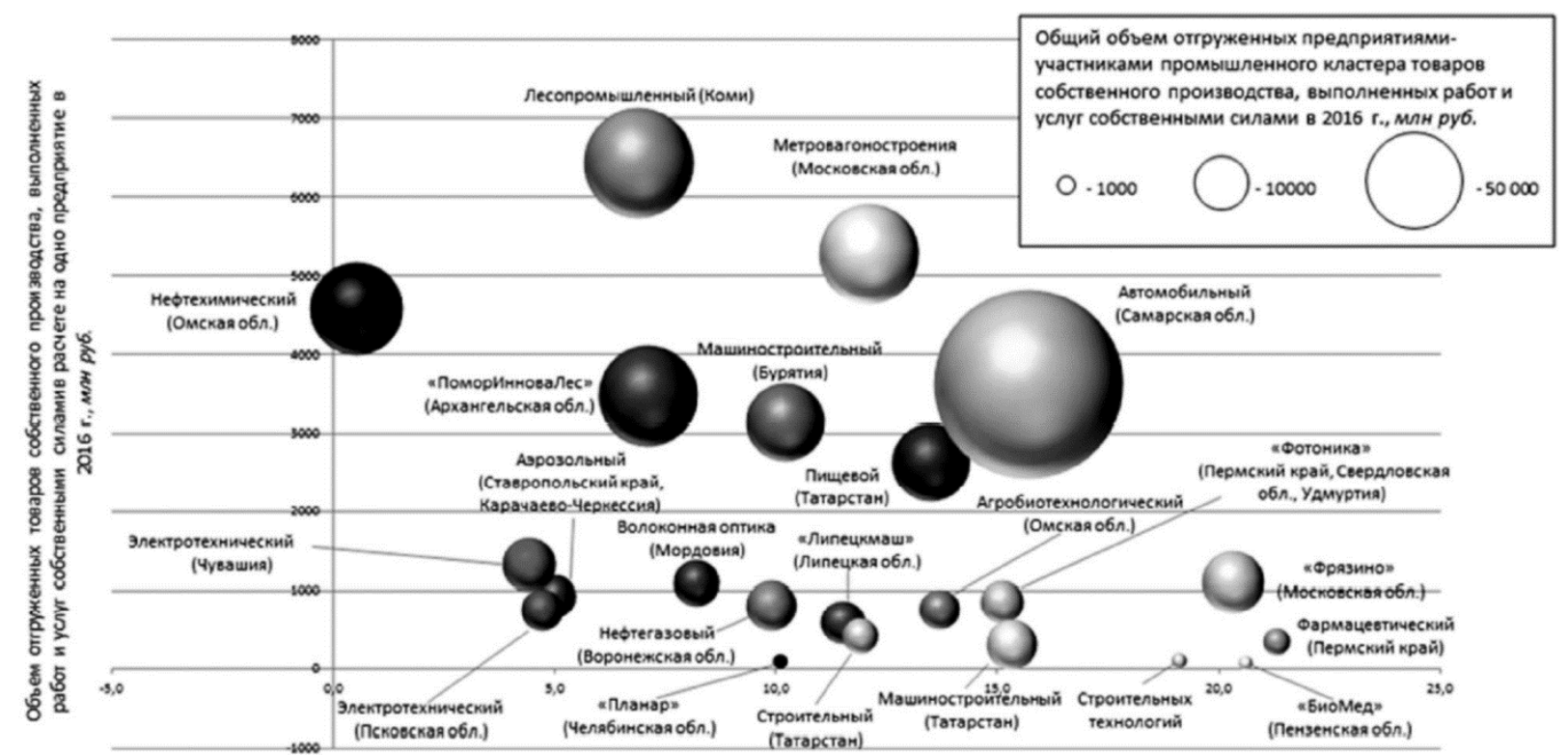

a) indicators of the volume of goods shipped by enterprises participating in industrial clusters of goods of own production [15, p. 51] 

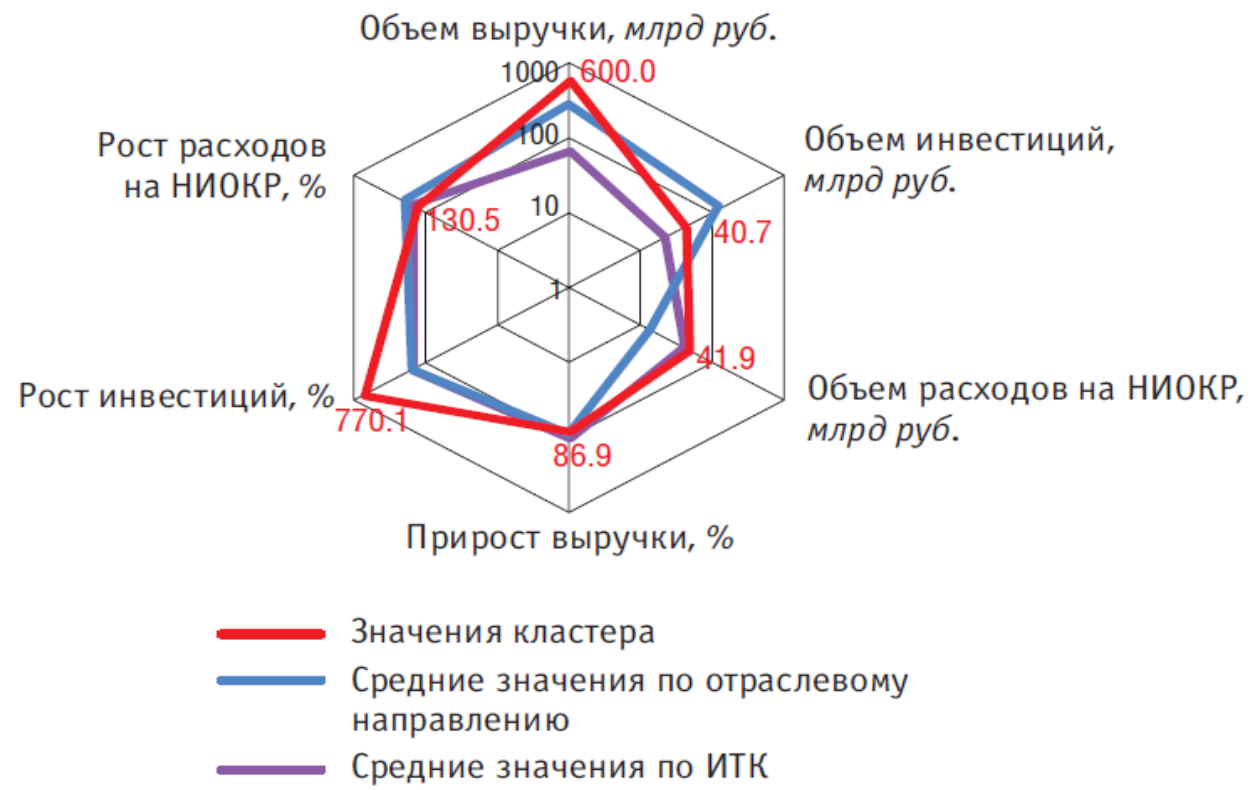

b) development parameters of the Kama innovative

territorial-production cluster of the Republic of Tatarstan [17, p. 101]

Fig. 2. Examples of clusters quantitative characteristics visualization

As a rule, scientists use graphical methods when constructing these models, including, most widely, the mapping method. This is due to the need to correlate spatial characteristics with attributive ones.

We would like to note that the specialists of the Russian Cluster Observatory of the ISSEK NRU HSE initiated and developed the project "Map of Russian Clusters" [2]. The aim of the project is to create an open, relevant, interactive database of clusters in the regions of Russia. The tool contains data on the number, scale of activity, industry focus, maturity and other important characteristics of Russian clusters. A fragment of the map is shown in Figure 3 .

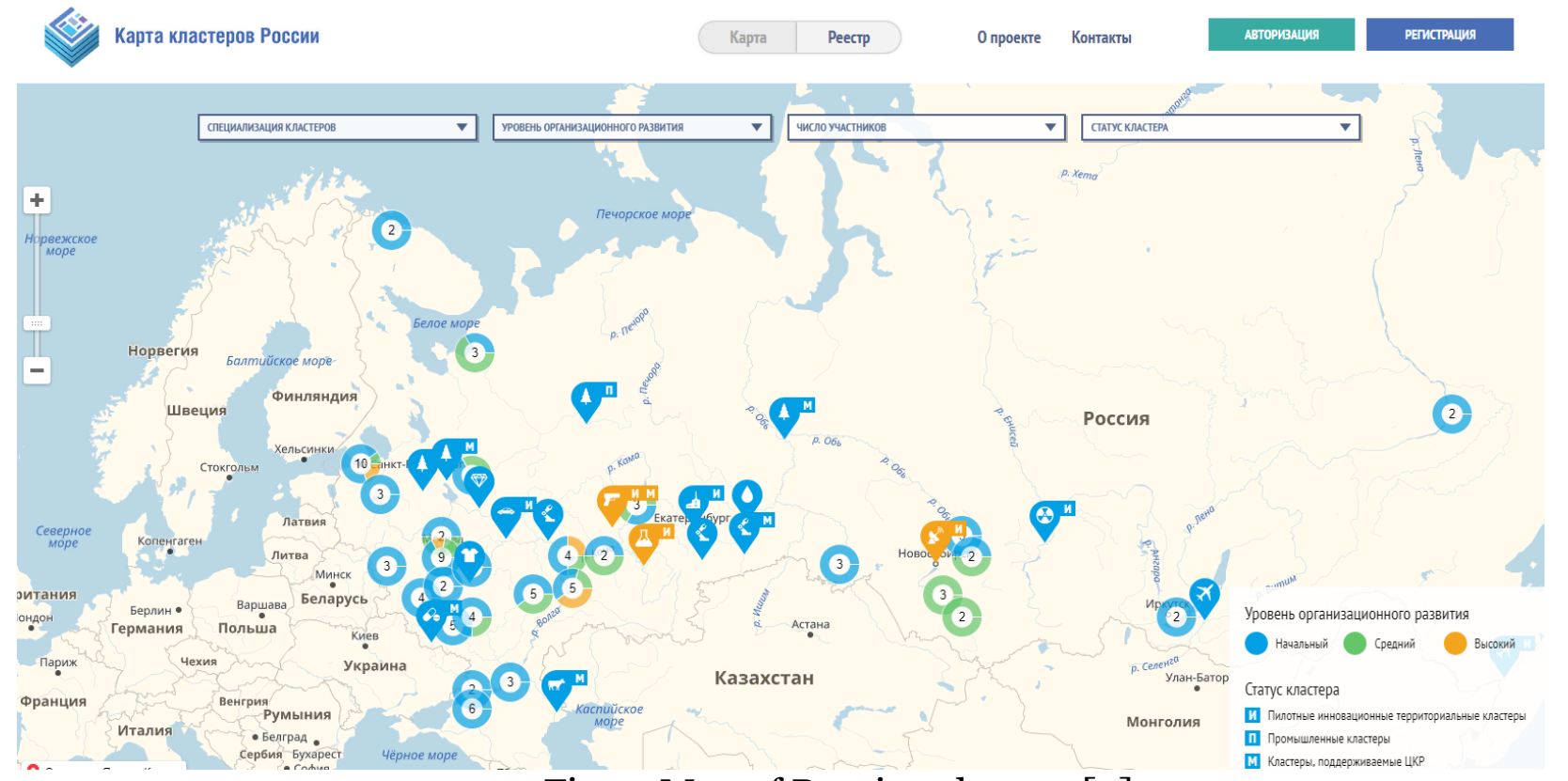

Fig. 3. Map of Russian clusters [2] 
The described methods of visualization within the framework of the models of the second group fully allow to perceive, evaluate and analyze the relevant information. But, like the models of the first group, they do not provide fully the capabilities of forecasting and strategic planning.

In the third group, we included works with a visual representation of author's calculations in the field of quality and prospects for clustering. As a rule, the quality of clusters is assessed by calculating the integral clustering indices, including indicators of management quality and indicators of interaction (integration) of participants [19, p. 32-33; 15, p. 49] levels of development and scale of clusters [20, p. 158; 21, p. 175; 22, p. 152]. Examples of models visualizing author's calculations of cluster quality indicators are presented in Figure 4.

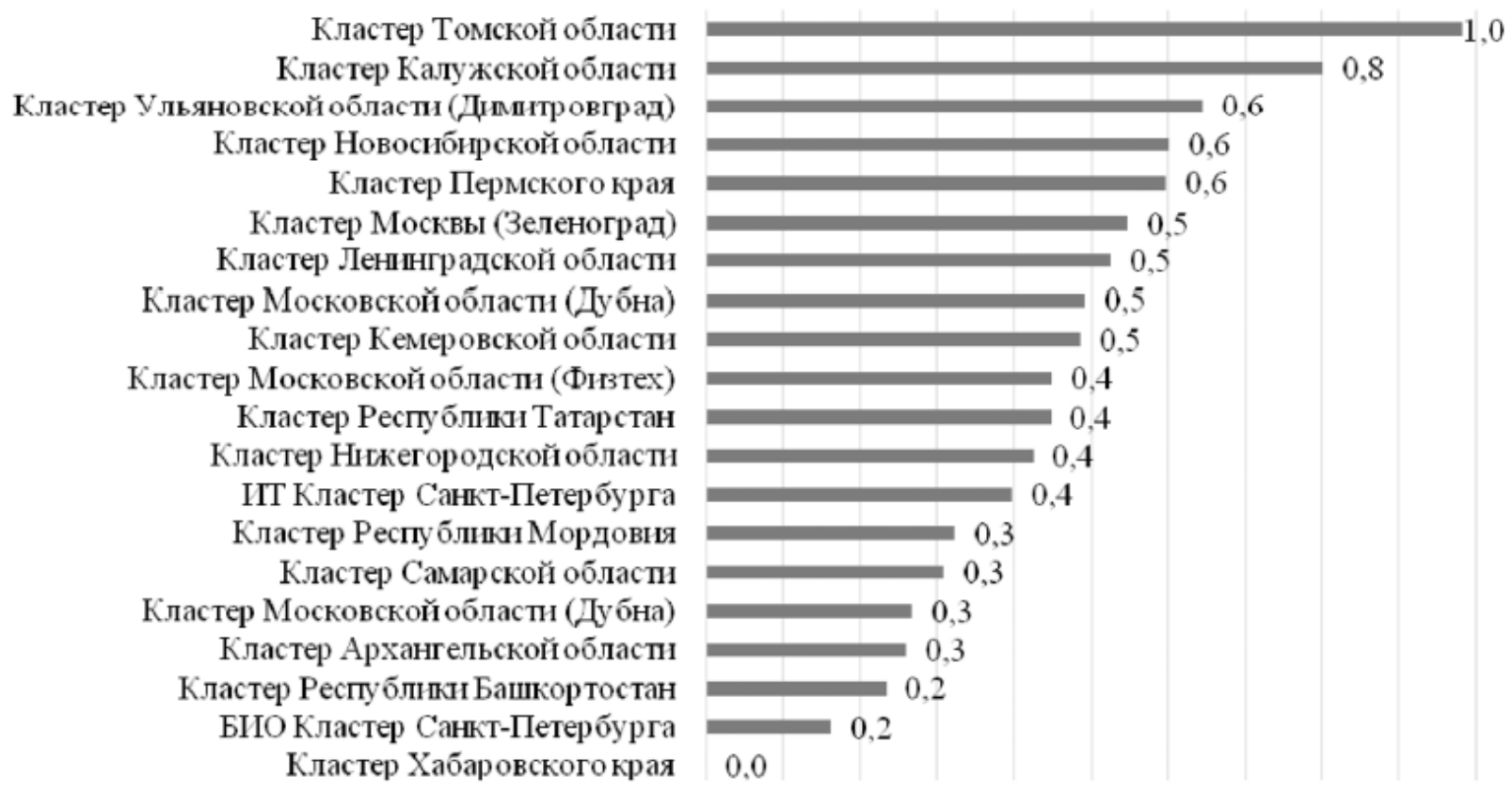

a) cluster management quality index [19, p. 33]

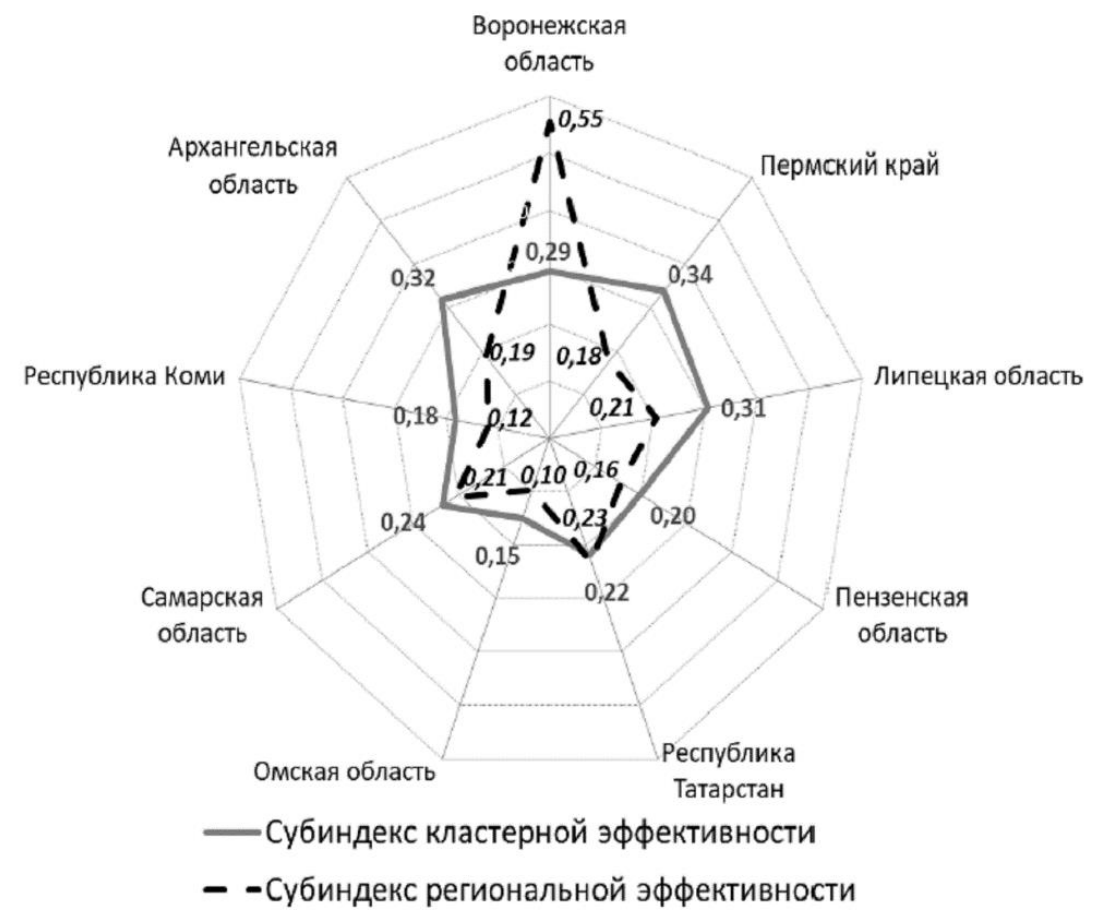

b) subindexes of cluster and regional effectiveness of the

Russian Federation constituent entities [21, p. 175]

Fig. 4. Examples of visualization of author's calculations for cluster quality indicators 
Speaking of examples of models that visualize the author's calculations of the prospects for clustering, let us explain what is meant by the assessment of territories, industries, or types of economic activity for their readiness for clustering. In fact, such an assessment involves the identification of territories, industries, or types of economic activity that could potentially provide the maximum return on investment. Based on the results obtained, decisions are made to support specific cluster development programs.

As a rule, the assessment of the clustering prospects, and accordingly, the construction of development forecasts on this basis, are carried out by analyzing the concentration of activity in space by calculating various indices and coefficients: Gini coefficient [23]; the Ellison Glazer index [24]; Marel - Sedilott index [25], Duranton - Overman index [26]; localization coefficient [22, 27-34]. Figure 5 .

Examples of models visualizing the clustering prospects assessments are presented in

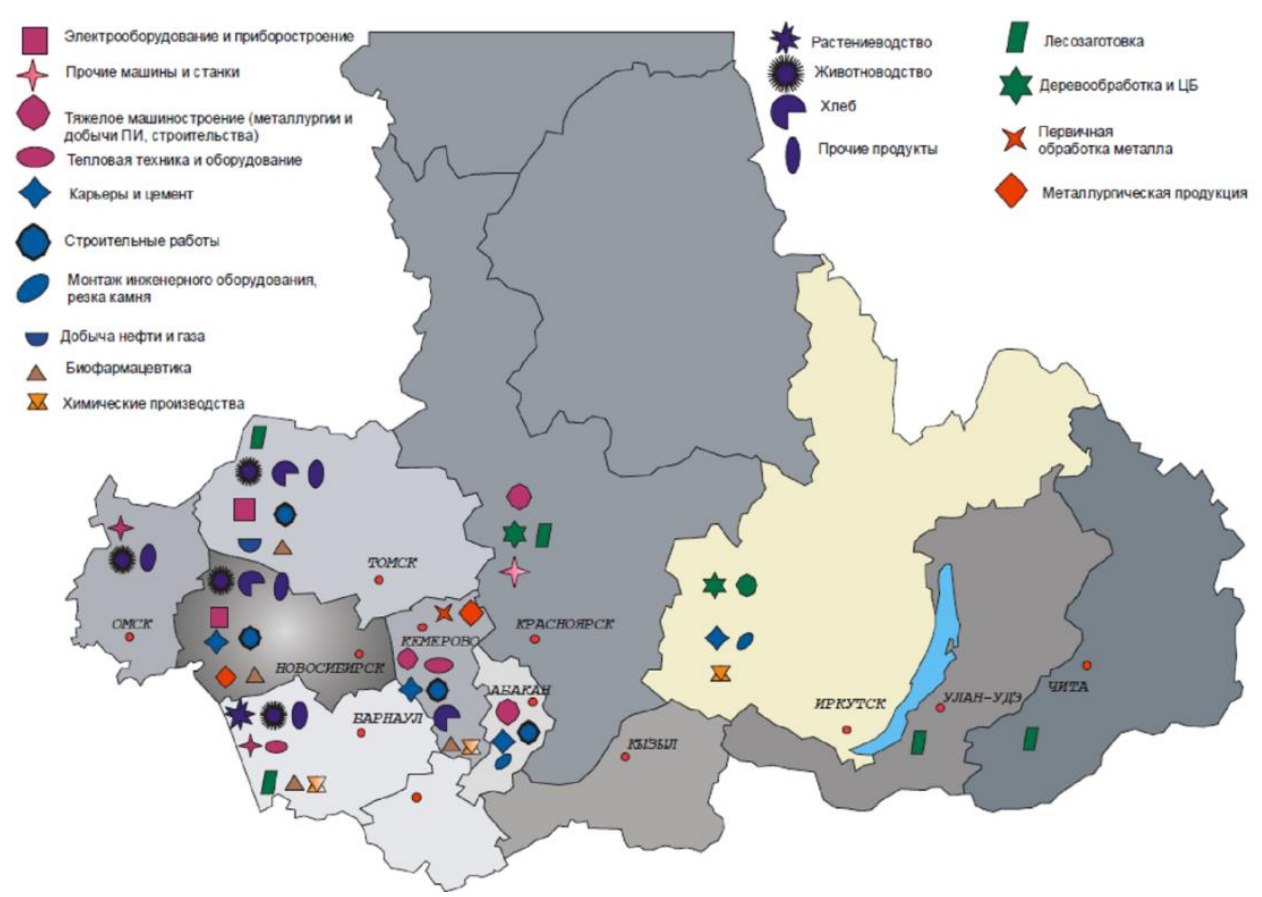

a) regional diversified clusters of Siberia [11, p. 102]

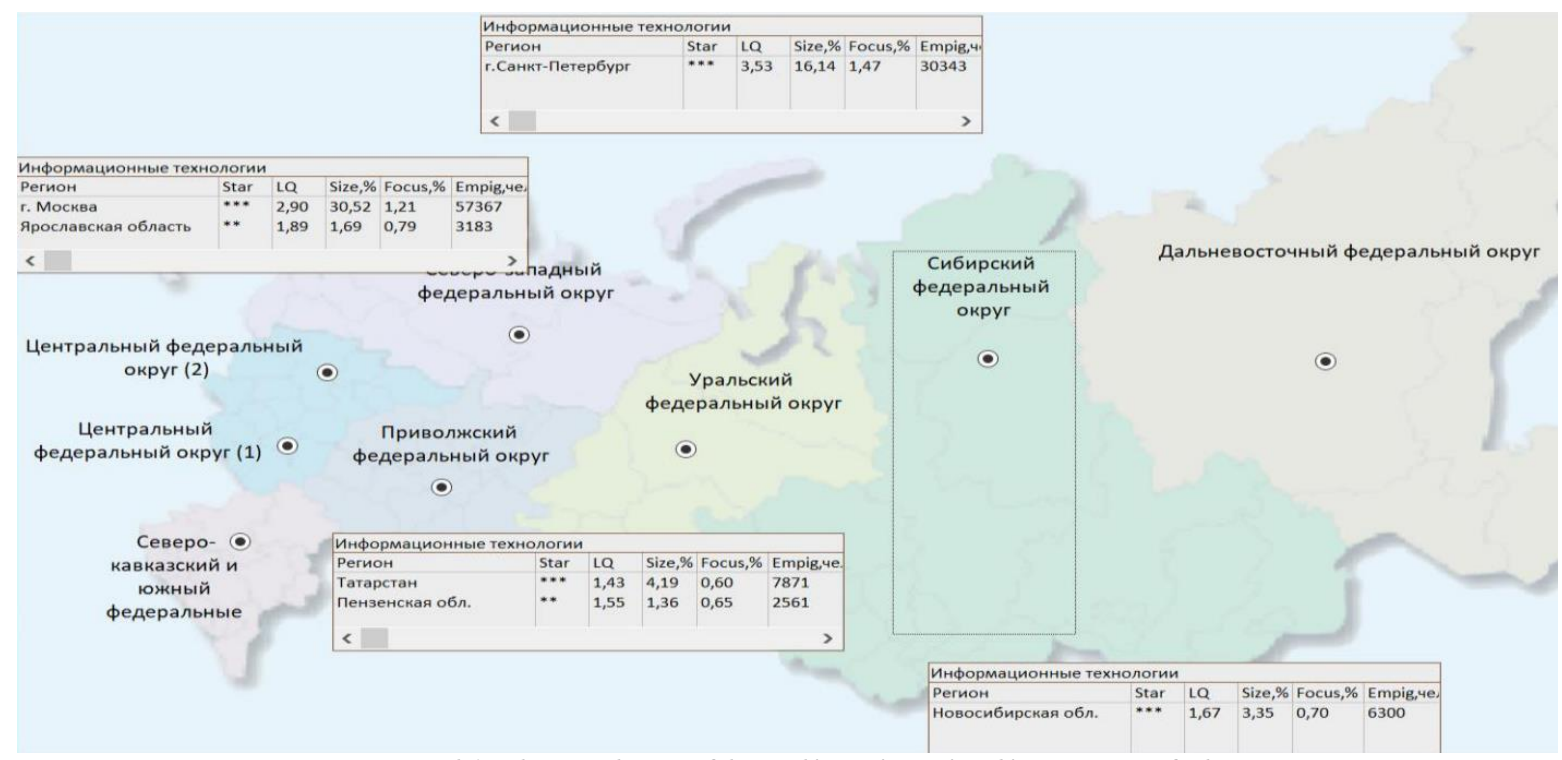

b) the value of localization indicators of the cluster Information Technology in Russia [13, p. 22]

Fig. 5. Examples of visualization of the clustering prospects assessment 
Special attention is to be paid to assessment of the clustering prospects based on graph theory. As a rule, the graphs are use for visualization of direct relationships identified in the analysis of the intersectoral balance tables. Various methods of graph partitioning are involved when using it as an independent tool for identifying clusters; an industrial cluster is a distinguished component of the connectedness of the original graph in the process of using it. [35, p. 97]. Note that we have found examples of visualization of clustering prospects based on graph theory only in relation to individual sectors of the economy (Fig. 6).

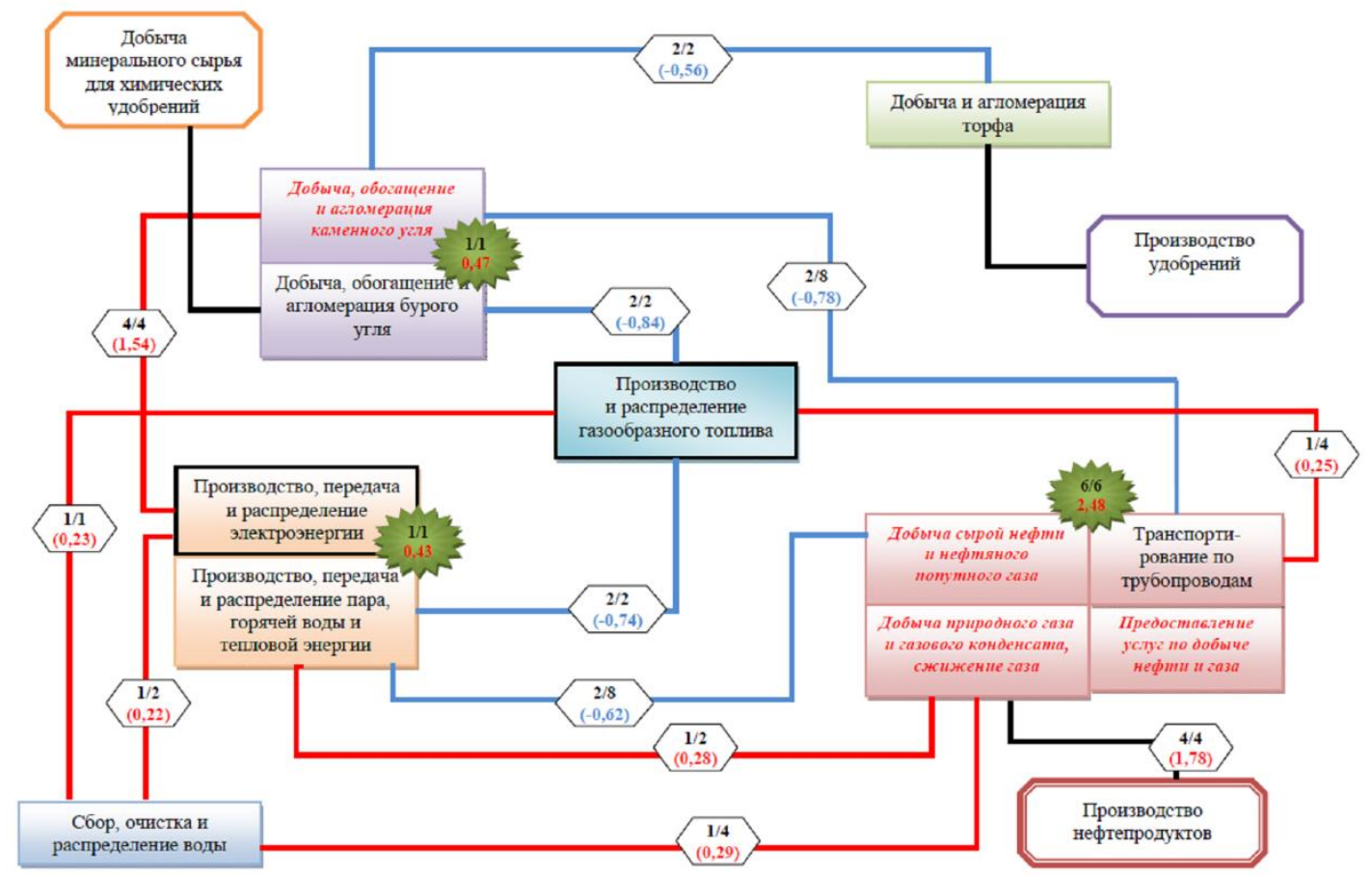

a) the relationship between cluster-forming activities of a cluster of fuel and energy industries [35, p. 104]

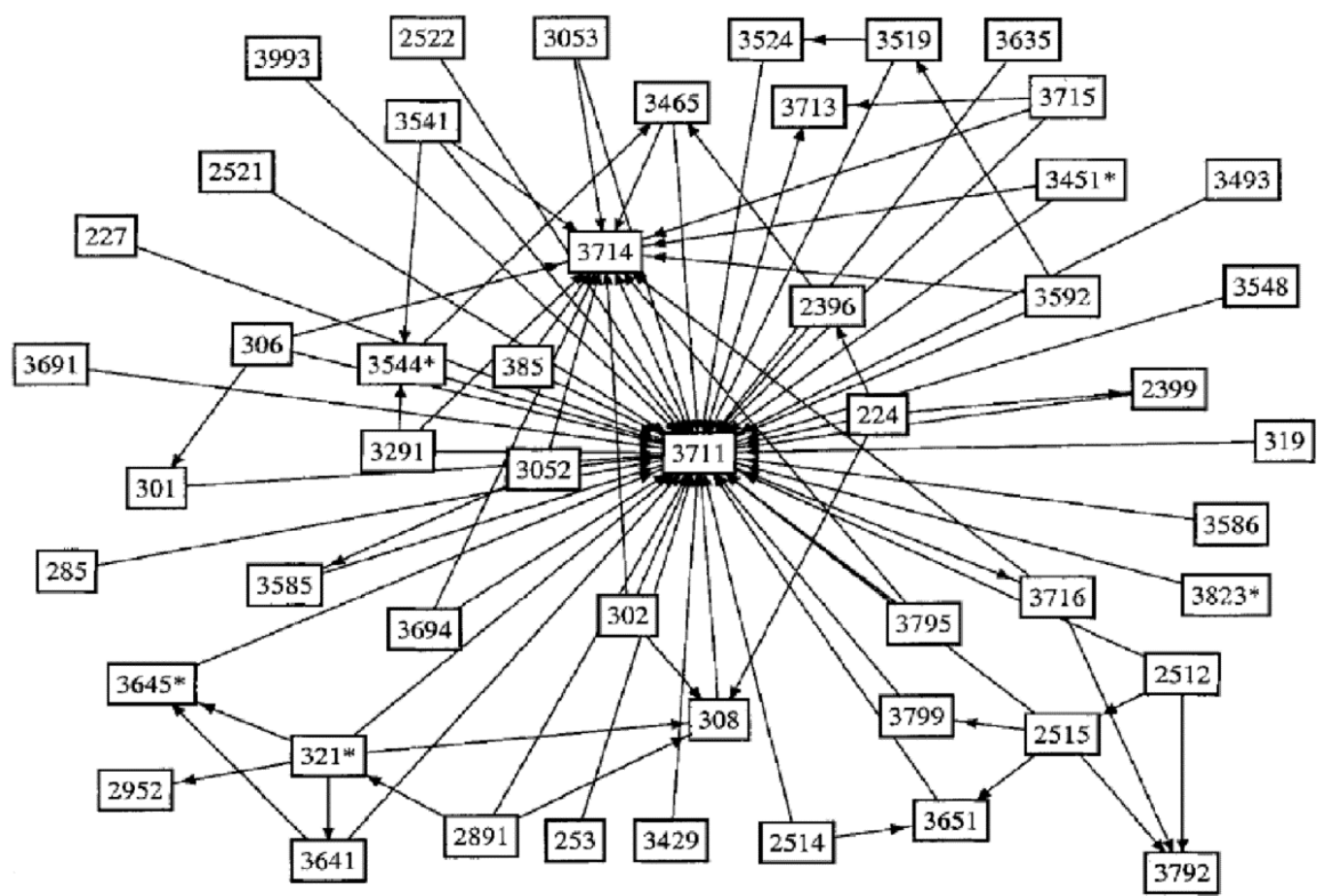

b) the relationship between cluster-forming activities of the transport cluster [36, p. 11] Fig. 6. Examples of clustering prospects visualization based on graph theory 
Summarizing the analysis of the research works of the third group, we note that models that include author's calculations in the field of quality and clustering prospects fully allow us to predict the behavior of the clustered industry, and therefore make it possible to draw up justified forecasts of the cluster enterprises development and adequate strategies for territorial development. At the same time, we did not find an accessible visual display of such calculations, which implements the function of convenient information perception.

One of the modern practical tools for visualizing relational data is GVMap, implemented in the Graphviz software. The GVMap tool displays clustered data in a geographic-like maps format, which makes it easier to read the graph of economic connectivity of industries. Data in the form of a graph is supplied as input parameters, and information on clustering in the data is also provided. The effectiveness of this tool is presented and demonstrated in [37]. Based on the results of testing GVMap in various fields of activity (services, sales, etc.), as well as on the results of our systematization of existing methods for visualizing the relationships between cluster entities, we determined the purpose of this study: creating a visualization technique for identifying industrial clusters using GVMap tool. Note that the scientific and practical significance of the author's technique lies in the possibility of modeling and predicting the behavior of a clustered industry.

\section{Algorithm for identifying industrial clusters based on maximum method and S. Zamanski's method}

The author's algorithm for assessing the prospects for clustering of domestic economy sectors is described in this part of the work, which was implemented within GVMap environment for for computer visualization. This algorithm allows to determine the most closely related groups of industries at the macro level, i.e. identify industrial clusters.

The identification of industrial clusters is based on the data of the symmetric inputoutput table (SIOT) for 2011 in the context of 86 types of economic activity in Russia. The table was published only at the beginning of 2017, since its compilation is a long and laborious process. The next release of SIOT is planned in 2022.

SIOT reflects information on "pure" industries, i.e. it is understood that each industry produces only its own type of product. Moreover, the lines of the industry are reflected as producers, and by the columns - as consumers. At the intersection of the i-th row and the j-th column, there is information on the quantity of products of the i-th industry (in monetary terms) spent on the production needs of the j-th industry.

Conversion of SIOT data for the distant clusters identification is carried out according to the method proposed by S. Zamansky (steps 1.1-1.4).

Step 1.1. Formation of matrices $X$ and $Y$, whose elements are equal:

$$
\begin{aligned}
& x_{i j}=a_{i j} / \sum_{k=1}^{n} a_{k j} \\
& y_{i j}=a_{i j} / \sum_{k=1}^{n} a_{i k}
\end{aligned}
$$

where $a_{i j}$ - the monetary value of deliveries by industry i for a certain period of industry $\mathrm{j}$ (element of the symmetric Input-Output table);

$x_{i j}$ - intermediate purchases by industry $\mathrm{j}$ from industry $\mathrm{i}$ in proportion to total purchases by industry $\mathrm{j}$;

$y_{i j}$ - intermediate sales from industry $\mathrm{i}$ industry $\mathrm{j}$ in proportion to total industry sales;

$\mathrm{n}$ - number of industries in SIOT $(\mathrm{n}=86)$.

Thus, we get the matrices $\mathrm{X}$ and $\mathrm{Y}$, while the columns of the matrix $\mathrm{X}$ are samples of purchases, and the columns of the matrix $Y$ are samples of sales of the respective industries. For any two branches $\mathrm{l}$ and $\mathrm{m}$, vectors $\mathrm{Xl}$ and $\mathrm{Xm}$, which are columns of the matrix $\mathrm{X}$, as well as vectors $\mathrm{yl}_{\mathrm{l}}$ and $\mathrm{ym}$, which are columns of the matrix $\mathrm{Y}$, can be defined. 
Step 1.2 Determination of the relationship (similarity) between any pairs of industries using correlation analysis.

To determine the similarity of pairs of industries, 4 matrices are calculated with Pearson's correlation coefficients [38]:

- Matrix XX, which elements $\mathrm{r}\left(\mathrm{xl}, \mathrm{x}_{\mathrm{m}}\right)$ measure the degree of similarity of purchases samples in industries $\mathrm{l}$ and $\mathrm{m}$;

- The matrix YY, which elements $\mathrm{r}(\mathrm{yl}, \mathrm{ym})$ measures the degree of similarity of sales samples in industries $\mathrm{l}$ and $\mathrm{m}$;

- The matrix XY, which elements $\mathrm{r}(\mathrm{xl}, \mathrm{ym})$ reflects the similarity of purchases samples in industry $l$ and sales samples of industry $\mathrm{m}$, i.e. how much industry $\mathrm{l}$ is involved in puchases from industries for which industry $\mathrm{m}$ is a supplier;

- The matrix YX, which elements $\mathrm{r}\left(\mathrm{yl}, \mathrm{x}_{\mathrm{m}}\right)$ reflects the similarity of purchases samples of industry $\mathrm{m}$ and sales samples of industry $\mathrm{l}$, i.e. the extent to which industry $\mathrm{m}$ participates in purchases from industries for which industry lis a supplier.

Step 1.3 Construction of a symmetric matrix $L v$.

The matrix elements are $\mathrm{lv}_{\mathrm{ij}}=\max \left(\mathrm{xx}_{\mathrm{ij}}, \mathrm{yy}_{\mathrm{ij}}, \mathrm{xy}_{\mathrm{ij}}, \mathrm{yx}_{\mathrm{ij}}\right)$, provided that the correlation coefficient is significant, i.e. $p$-value $<0.05$.

Each column of the Lv matrix is an example of the relationship between the industry located in the column and all other manufacturing industries. Thus, in the Lv matrix for each industry, measures of indirect and direct intersectoral communication are calculated.

Step 1.4 Isolation of industrial clusters using the principal component analysis (PCA)

The columns of the Lv matrix are variables for the principal component method. The purpose of applying this method is to "compress" the original number of variables. Thus, the minimum number of factors, called the main components and contributing most to the variance of the data, is determined. The main components help structure a complex data set, identify the most informative variables, and also allow you to switch to uncorrelated variables.

The search for the main components is performed in several actions:

- standardization of source data;

- obtaining eigenvectors and eigenvalues of the covariance matrix or correlation matrix;

- sorting the eigenvalues in descending order and choosing $k$ eigenvectors corresponding to $\mathrm{k}$ largest eigenvalues, where $\mathrm{k}$ is the dimension of the new functional subspace $k \leq d$;

- constructing a projection matrix W consisting of selected $\mathrm{k}$ eigenvectors;

- transforming the original data set $\mathrm{X}$ through $\mathrm{W}$ in order to obtain the k-dimensional functional subspace $\mathrm{Y}$.

The number of largest eigenvalues of $k$ is determined by the Kaiser criterion: eigenvalues greater than 1 are selected. In essence, it means that if the component does not emit a variance equivalent to at least the variance of one variable, then it is omitted.

As a result of the first 4 steps of the algorithm, 11 industrial clusters characteristic of the Russian economy were identified: a metalworking cluster, a chemical industry cluster, a food industry cluster, a mining cluster, a forestry cluster, woodworking and pulp and paper processing, a non-ferrous and precious metal processing cluster, building materials cluster, light industry cluster, oil and gas industry cluster, coal industry cluster, high technological equipment and IT.

Step 1.5 Building a matrix of "follow-up links" $C$.

To build links between the vertices of the graph (edges) of the clusters, the main suppliers and buyers of industries were calculated using the Maximum method (steps 1.5-1.7). The SIOT analysis, based on the maximum method, is widely used to identify clusters. The mathematical apparatus of this method was first disclosed in the work of M. Montfort and D. Dutelli [39]. The essence of the approach proposed by the authors is to identify value chains, 
while intra-industry relations are not taken into account, i.e. the main diagonal SIOT takes on zero values.

In the table "Input-output", the lines of manufacturers contain information on the volumes of consumption of their products by various industries.

The main consumer $\mathrm{l}$ of the industry $\mathrm{k}\left(c_{k l}\right)$ is determined by the formula (3):

$$
c_{k l}=\max _{j} a_{k j}
$$

where $a_{k k}=0, j=\overline{1, n}, a_{i j}$ - element of the matrix "Cost-Release" size $n \times n$.

Next, the significance of deliveries to the main consumer is checked by comparing the share of deliveries to a given consumer of the total supply with a certain empirically set threshold value $(\lambda)$.

As a result, the binary matrix C (4) of the "subsequent links" is constructed, in which the element is 1 if the relationship between the supplier and the consumer is significant, that is:

$$
\left\{\begin{array}{l}
c_{i j}=1, \text { if } \frac{c_{k l}}{\sum_{j} a_{k j}}>\lambda \\
c_{i j}=0, \text { if } \frac{c_{k l}}{\sum_{j} a_{k j}} \leq \lambda
\end{array}\right.
$$

Step 1.6 Building a matrix of "previous links" $S$.

At this step, the main suppliers of industries are determined. The construction of the binary matrix $\mathrm{S}$ of the "previous links" occurs similarly to the construction of the matrix of "subsequent links".

The main supplier $\mathrm{k}$ of industry $\mathrm{l}$ is determined by the formula (5):

$$
s_{k l}=\max _{i} a_{i l}
$$

where $a_{i i}=0, i=\overline{1, n}, a_{i j}$ - input-output matrix element of size $n \times n$.

Next, the binary matrix $\mathbf{S}(6)$ of significant suppliers of consumer industries is filled:

$$
\left\{\begin{array}{l}
s_{i j}=1, \text { if } \frac{s_{k l}}{\sum_{i} a_{i l}}>\lambda \\
s_{i j}=0, \text { if } \frac{s_{k l}}{\sum_{i} a_{i l}} \leq \lambda
\end{array}\right.
$$

Step 1.7 Building a matrix of significant relationships supplier-consumer CS:

$$
c s_{i j}=c_{i j}+s_{i j}
$$

As a result, some elements of the CS matrix will be equal to 2, which indicates a significant relationship both in purchases and in supply.

To automate the process of identification of industrial clusters and their visualization, a software tool was created in. 


\section{Visualization of industrial clusters using a GVMap tool}

The visualization of industrial clusters was performed using the GVMap tool, which converts a graph into a map in a geographical style with clusters highlighted in the form of countries (Ошибка! Источник ссылки не найден.7).

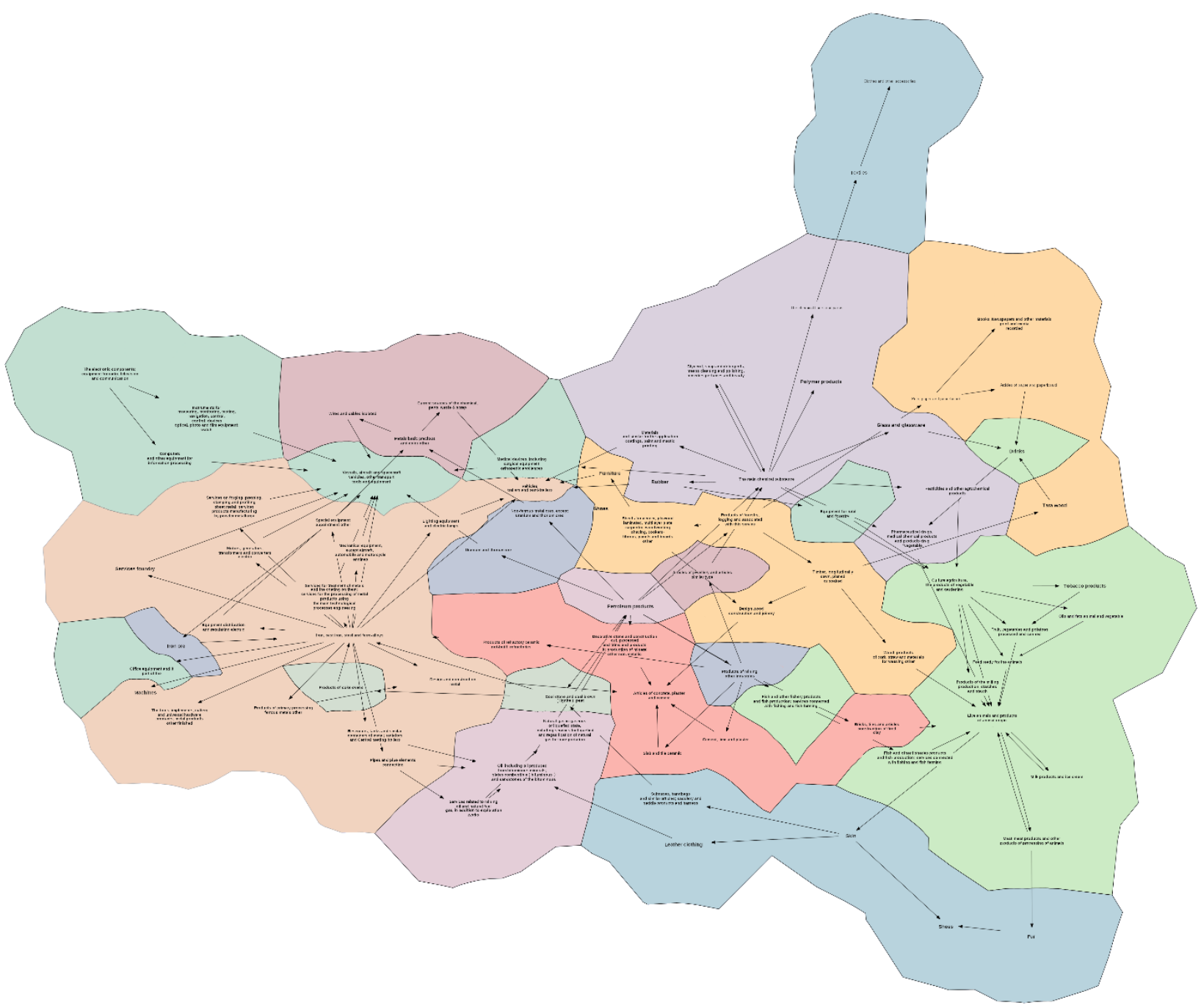

Fig. 7. Visualization of industrial clusters using GMap

In our case, the vertices of the graph are the types of economic activity, the relationships between the vertices of the graph (edges) are built on the basis of the matrix of significant supplier-consumer relationships obtained by the Maximum method (steps 1.5-1.7). Industrial clusters are determined using the method proposed by S. Zamansky (steps 1.1-1.4).

The constructed graph map contains aggregated information about the connections between the Russian industries. You can determine the groups of interconnected industries by color, and you can track value chains by the direction of the edges.

The graph contains 82 vertices and 129 edges. All vertices have at least one connection with a neighboring vertex. The largest number of neighbors have such peaks as: "Iron, cast iron, steel and ferroalloys" - 20 neighbors, "Ships, aircraft and spacecraft, other vehicles and equipment" - 12 neighbors, "Live animals and animal products" - 13 neighbors.

Consider several "countries" on the map in more detail.

In the southeast lies the industrial cluster of the food industry (light green color), the center of which is the type of activity "Live animals and animal products", which is associated with almost all types of activity in the cluster (Fig. 8). Note that the map can not only trace 
value chains, but also identify potential industries - suppliers / consumers of the industry we are interested in, and not only in the "related" industry. So, for example, to search for suppliers to enterprises producing crops, you should pay attention to the chemical industry. If, for example, the beverage company needs to expand the list of consumers, then the map can determine that the potential buyers of their products are chemical industries.

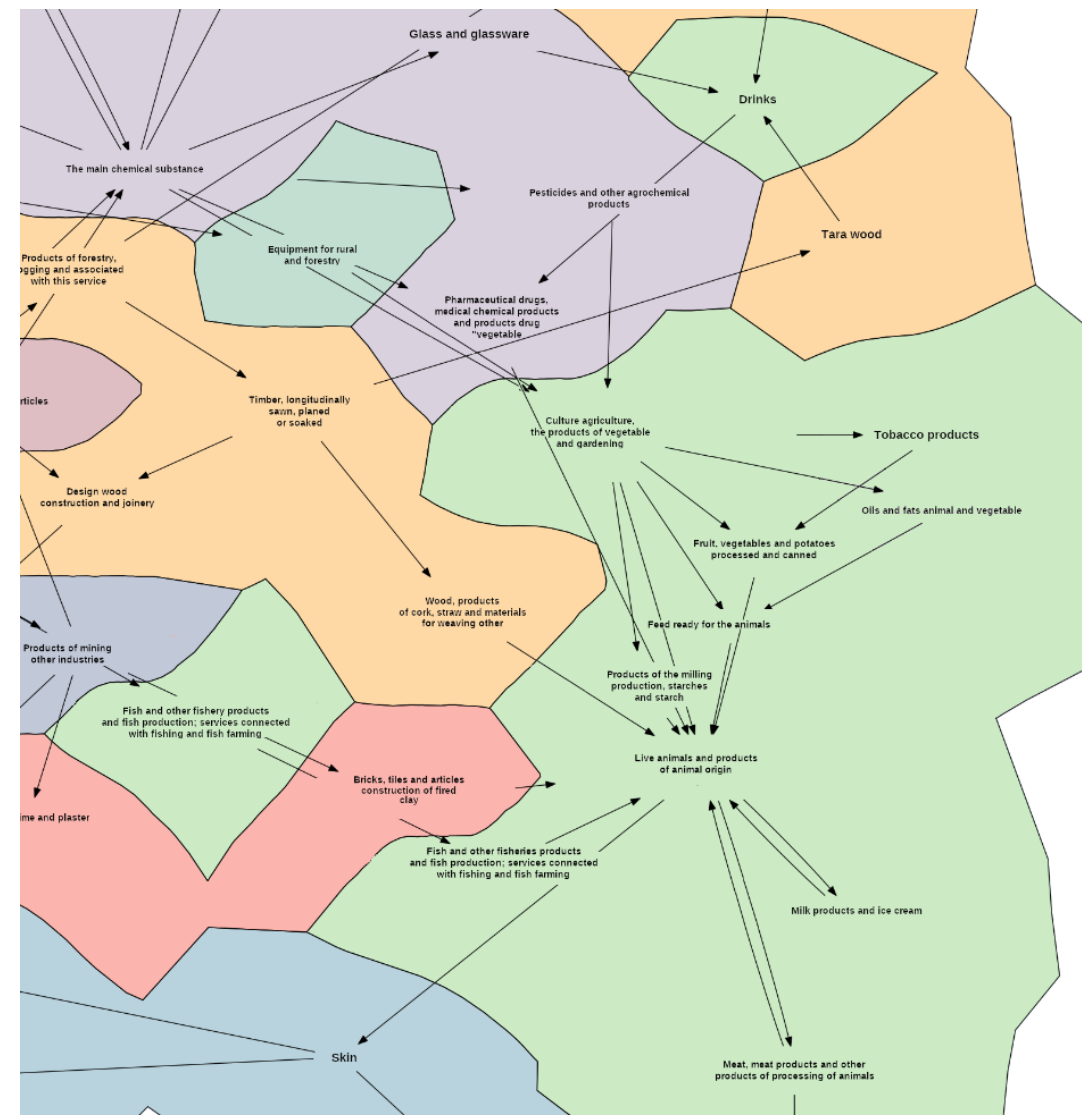

Fig. 8. The food industry cluster

In the south of the map there is a part of the light industry cluster (blue color). The map shows that the manufacturers of this cluster supply most of their products to coal enterprises and the oil and gas industry. This is because overalls used by enterprises in these industries are made of leather. In turn, the food industry is the main supplier of light industry (Fig. 9).

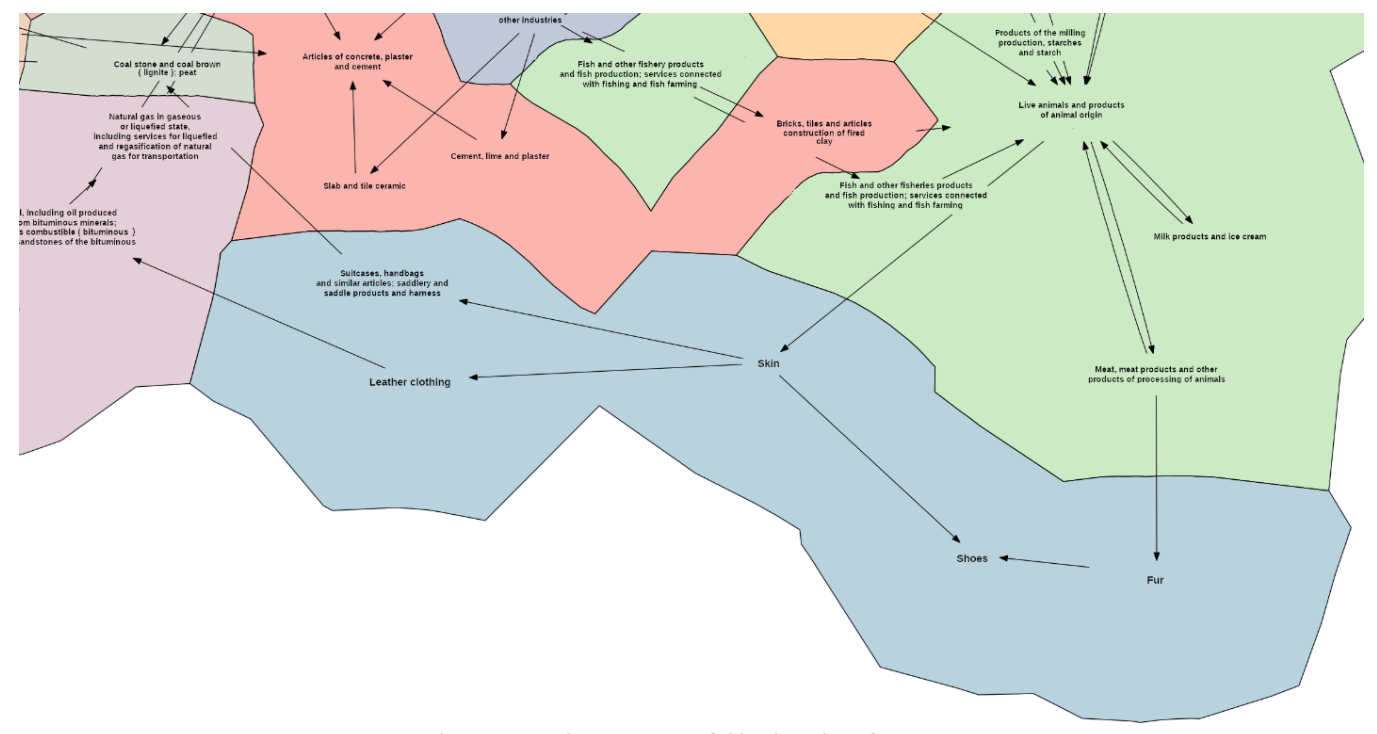

Fig. 9. Cluster of light industry 
Thus, the map of industrial clusters constructed using the GVMap tool can be useful in strategic planning of the development of all levels of the economy: macro level (country), meso level (region), micro level (enterprise).

\section{Conclusion}

The paper presents a computer visualization technique for identifying industrial clusters using the GVMap tool. The methodology was based on the experience of testing GVMap in various fields of activity, as well as the results of the systematization of existing methods for visualizing the relationships between the subjects of the cluster.

The basis of visualization is the author's mathematical algorithm for identifying industrial clusters, compiled using the maximum method, S. Zamanski method and graph theory.

The advantages of the proposed visualization method are as follows. Firstly, the results of the clusters identification fully allow prediction of the behavior of the clustered industry, and therefore make it possible to make both reasonable forecasts for the development of cluster enterprises and adequate strategies for territorial development. Secondly, the visual display of simulation results on a geographic-like maps image allows you to reflect all types of economic activity and the relationship between them in an easily readable format.

The described approach to the identification and visualization of industrial clusters was the basis for the creation of a software tool (web application) "Interregional Clusters of Russia", designed for the automated collection of statistical data from Internet sources and identification of inter-regional clusters based on them.

\section{References}

1. Ofitsial'nyy sayt Pravitel'stva Rossii. Obshchiye voprosy promyshlennoy politiki: nekotoryye vazhnyye resheniya i fakty za 6 let. [The official website of the Government of Russia. General issues of industrial policy: some important decisions and facts for 6 years]. (http://government.ru/info/32124/) [in Russian]

2. Karta klasterov RF [Map of clusters of the Russian Federation]. (https://cluster.hse.ru/mirror/pubs/share/22903938) [in Russian]

3. Andersson T., Serger S.S., Sorvik J., Wise Hannsson E. The cluster policies whitebook. IKED: Malmo, 2004.

4. Feser E.J. Old and new theories of industry clusters. From the Selected Works of E.J. Feser, 1998 (https://works.bepress.com/edwardfeser/3/)

5. Ketels Ch., Lindqvist G., Sölvell Ö. Strengthening clusters and competitiveness in Europe. The role of cluster organizations. (http://gosbook.ru/node/84334)

6. Sölvell Ö. Clusters. Balancing evolutionary and constructive forces. Second edition. Stock-holm: Ivory Tower Publ., 2009. 140 p.

7. Sölvell Ö., Lindqvist G., Ketels Ch. The cluster initiative greenbook. Stockholm: Ivory Tower Publ., 2003. 93 p.

8. Menshenina I.G., Kapustina L.M. Klasteroobrazovaniye v regional'noy ekonomike: monogr. [Clustering in the regional economy: monograph.] Ekaterinburg: Publishing House Ural. state econ University, 2008. 154 p. [in Russian]

9. Effektivnost' deyatel'nosti predpriyatiy $\mathrm{v}$ usloviyakh klasterizatsii $\mathrm{v}$ regionakh RF: monografiya [The effectiveness of enterprises in the conditions of clustering in the regions of the Russian Federation: monograph]/ I.I. Bogachev, T.F. Kreydenko, I.A. Rodionova; pod red. prof. I.A. Rodionovoy. - M .: University book, 2016 - 238 p. [in Russian]

10. Battalova A.A. Otsenka investitsionnoy klasterizatsii otrasli [Assessment of industry clustering potential] // Internet-journal "SCIENCE", № 6, 2013, pp. 1-8. [in Russian]

11. Klasternyye politiki i klasternyye signaly: teoriya, metodologiya, praktika. [Cluster policies and cluster initiatives: theory, methodology, practice] / under. ed. Yu.S. Artamonova, B.B. Khrustaleva. Penza: IP Tugushev S.Yu., 2013. 230 p. [in Russian] 
12. Kaplina A.V. Analiz modeley formirovaniya klasternykh struktur v sisteme regional'noy ekonomiki [Analysis of the models of the formation of cluster structures in the system of the regional economy: the managerial aspect] // Economic Sciences, № 5 (114), 2014, pp. 57-62. [in Russian]

13. Kudryavtseva T.YU. Teoriya, metodologiya i instrumentariy formirovaniya klasternoy promyshlennoy politiki [Theory, methodology and tools for the formation of a cluster industrial policy], Sankt-Peterburg: Thesis for the degree of Doctor of Economic Sciences, 2018. [in Russian]

14. Abashkin V.L., Boyarov A.D., Kutsenko Ye.S. Klasternaya politika v Rossii: ot teorii k praktike [Cluster policy in Russia: from theory to practice] // Forsyth, Vol. 6, no. 3, 2012, pp. 16-27. [in Russian]

15. Kutsenko Y.S., Abashkin V.L., Fiyaksel E.A., Islankina Y.A. Desyat' let klasternoy politiki v Rossii: logika vedomstvennykh podkhodov [Ten years of cluster policy in Russia: the logic of departmental approaches] // Innovations, No. 12 (230), 2017, pp. 46-58. [in Russian]

16. Akinfeyeva Y.V. Formirovaniye i razvitiye vklyuchayut klasterov. [Formation and development of regional clusters]. (http://riep.ru/upload/iblock/103/ 103a3a3fa5e5aodca75838b37af5a83d.pdf) [in Russian]

17. Pilotnyye innovatsionnyye territorial'nyye klastery v Rossiyskoy Federatsii [Pilot innovative territorial clusters in the Russian Federation] / ed. L.M. Gokhberg, A.E. Shadrina. M .: Izd. HSE House, 2013. 110 p. [in Russian]

18. Prokhorova V.V., Khachaturova M.S. Funktsii i instrumenty razvitiya klasterov v regional'noy ekonomike sovremennoy Rossii: monogr. [Functions and tools for the development of clusters in the regional economy of modern Russia: monograph] Maykop, 2015. 144 p. [in Russian]

19. Stanovleniye innovatsionnykh klasterov v Rossii: itogi pervykh let podderzhki []The formation of innovation clusters in Russia: the results of the first years of support] / I.M. Bortnik, S.P. Zemtsov, O.V. Ivanova [et al.] // Innovations, No. 7 (201), 2015, pp. 26-36. [in Russian]

20. Markov L.S. Teoretiko-metodologicheskiye osnovy klasternogo podkhoda: monogr. [Theoretical and methodological foundations of the cluster approach: monograph] / IEPP SB RAS. Novosibirsk, 2015. 300 p. [in Russian]

21. Otsenka effektivnosti klasternogo prostranstvennogo razvi-tiya regionov: teoretikometodologicheskiy podkhod: monografiya [Assessment of the effectiveness of cluster spatial development of regions: a theoretical and methodological approach: a monograph] / T. Yu. Kovaleva, E. V. Bazueva, E. D. Oborina, P. A. Sukhanova; under total ed. T. Yu. Kovaleva; Perm. state nat researches un-t - Perm, 2017. - 280 p. [in Russian]

22. Mirolyubova T.V., Karlina T.V., Kovaleva T.Y. Zakonomernosti i faktory formirovaniya i razvitiya vydelennykh klasterov: monogr. [Patterns and factors of formation and development of regional clusters: monograph] / Perm. state nat researches un-t Perm, 2013. 283 p. [in Russian]

23. Krugman P. Increasing returns and Economic Geography // Journal of Political Economy, No. 99, 1991, pp. 483-499.

24. Ellison G., Glaeser E.L. Geographic concentration in U.S. manufacturing industries: a dartboard approach // Journal of Political Economy, No. 105, 1997, pp. 889-927.

25. Maurel F., Sedillot B. A measure of the geographic concentration in french manufacturing industries // Regional Science and Urban Economics, Vol. 29, 1999, pp. 575-604.

26. Duranton G., Overman H. Testing for localization using micro-geographic data // Review of Economic, Studies 72, 2005, pp. 1077-1106.

27. Held J.R. Clusters as an economic development tool: beyond the pitfalls // Economic Development Quarterly, No. 10, 1996, pp. 249-261.

28. Crawley A., Beynon M., Munday M. Making location quotients more relevant as a policy aid in regional spatial analysis // Urban Studies, No. 50, 2013, pp. 1854-1869. 
29. Isaksen A. Towards increased regional specialization? The quantitative importance of new industrial spaces in Norway, 1970-1990 // Norsk Geografisk Tidsskrift, No. 50, 1996, pp. $113-123$.

30. Braunerhjelm P., Carlsson B. Industry Clusters in Ohio and Sweden, 1975-1995 // Small Business Economics, No. 12, 1999, pp. 297-290.

31. Sternberg R., Litzenberger T. Regional clusters in Germany: their geography and their relevance for entrepreneurial activities // European Planning Studies. No. 12, 2004, pp. 767-792.

32. Brenner T. An Identification of Local Industrial Clusters in Germany // Regional Studies, No. 40(9), 2006, pp. 1-14.

33. Porter M. Location, Competition, and Economic Development: Local Clusters in a Global Economy//Economic Development Quarterly, No. 14(1), 2000, pp. 15-34.

34. Bergman E., Feser E. Industrial and Regional Clusters: Concepts and Comparative Applications. Virginia: WVU Regional Research Institute, 1999.

35. Markov L.S., Markova V.M. Vyyavleniye etalonnykh klasterov: metodicheskiye voprosy i prakticheskoye prilozheniye $\mathrm{k}$ otechestvennoy promyshlennosti [Identification of reference clusters: methodological issues and practical application to the domestic industry] // Bulletin of the NSU. Socio-economic sciences, vol. 12, no. 1, 2012, pp. 95-108. [in Russian]

36. Bergman Ed.M., Feser Ed.J. National Industry Cluster Templates: A Framework for Applied Regional Cluster Analysis // Regional Studies. Carfax Publishing. Vol. 34, № 1, 2000, pp. 1-19.

37. Gansner E., Hu Y., Kobourov S. GMap: Visualizing Graphs and Clusters as Maps. (http://citeseerx.ist.psu.edu/viewdoc/download?doi=10.1.1.154.8753\&rep=rep1\&type=pdf)

38. Czamanski S., Ablas, L. A. Identification of industrial clusters and complexes: a comparison of methods and findings // Urban Studies, № 16, 1979, pp 61-80.

39. Montfort, M. J., Dutailly, J. C. Les filieres de production // INSEE Archives et Documents, 1983, pp. 1-193. 